\title{
Water resistance of torrefied wood pellets prepared by two methods
}

\author{
Takahiro Yoshida ${ }^{1, *}$, Katsushi Kuroda ${ }^{1}$, Daisuke Kamikawa ${ }^{1}$, Yoshitaka Kubojima ${ }^{1}$, Takashi \\ Nomura $^{2}$, Hiroki Watada ${ }^{2}$, Tetsuya Sano ${ }^{3}$ and Seiji Ohara ${ }^{1}$ \\ 1 'Department of Wood Properties and Processing, Forestry and Forest Products Research Institute, National \\ Research and Development Agency Forest Research and Management Organization, 1 Matsunosato, \\ Tsukuba, Ibaraki, Japan; tyoshid@ffpri.affrc.go.jp \\ 2 Fukui Prefectural Green Center, Sakai, Fukui, Japan \\ 3 Department of Engineering, Tohoku Institute of Technology, Sendai, Japan \\ * Correspondence: tyoshid@ffpri.affrc.go.jp; Tel.: +81-29-829-8306 Fax.: +81-29-874-3720
}

\begin{abstract}
To examine the hydrophobicity of torrefied wood fuel, the water resistances of torrefied pellets prepared by two different methods were evaluated using exposure tests under indoor and outdoor conditions. Torrefied pellets from the xylem of Japanese cedar (Sugi, Cryptomeria japonica) and oak (Konara, Quercus serrata) were prepared by two methods: the torrefaction of wood chips followed by pelletization and the pelletization of wood chips followed by torrefaction. It was found that the pellets prepared by pelletization followed by torrefaction had much lower moisture levels than those prepared by the other method and they showed almost no change in diameter after an outdoor weathering test. These characteristics are unique and indicate that the pellets can be applied not only for industrial use but also for residential and commercial purposes.
\end{abstract}

Keywords: wood pellet; torrefaction; hydrophobicity; water resistance

\section{Introduction}

Biomass is an organic renewable energy resource that has properties distinct from solar and wind energy. Organic biomass resources synthesized using solar energy can be artificially stored and controlled both in handling and use. Further, woody biomass has the benefit of a stable supply because it does not compete with food utilization. The role of woody biomass as an energy resource is thus considered to be important for establishing a sustainable society. Fossil fuels, which have been used as one of our main energy resources, originate largely from biomass formed deep underground over long periods of time. However, comparing the properties of both the forms of energy, the energy density of biomass is normally lower than that of fossil fuels. This disadvantage results in low thermal output per volume during combustion and also leads to inefficient storage and transportation. As a method to increase its energy density, the densification of biomass into cylindrical pellets by minimizing variations in density and moisture content has been commercialized. However, pellets have the disadvantage that their shape collapses upon water uptake.

Thermal treatment has been conventionally used for a long time as a method for improving the properties of biomass, and there have been many studies on the use of wood materials in this respect [1]. Carbonization treatment converting into charcoal, is also known for upgrading calorific values of biomasss fuel. Recently, low-temperature heat treatment at approximately $250-300^{\circ} \mathrm{C}$ under the absence of oxygen, called torrefaction, combined with pelletization is demonstrated as a promising method to upgrade the characteristics of solid fuels, maximizing their energy density and achieving better hydrophobicity [2-4]. Thus, many research papers on torrefaction have been published worldwide, mainly for large-scale applications such as co-firing using coal. With regard to use on small scales, Yoshida et al. studied the effects of torrefaction treatment conditions, mass yields, and 
calorific values at a laboratory scale $[5,6]$. They then constructed a demonstration plant with a treatment amount of $20 \mathrm{~kg} / \mathrm{h}$ to continuously produce torrefaction chips from raw wood chips [7,8]. As a result of burning trials for the torrefied pellets in a commercial pellet stove, we found that the torrefied pellets demonstrated faster ignition time than normal pellets. We thus designed a commercial-scale plant to produce torrefied wood pellets at a small scale $(3,000 \mathrm{t}$ of torrefied fuel per year) using local wood resources [9]. However, as pointed out in the report, these pellets should have a higher cost than normal wood pellets in production $[2,4,9]$. Production at a large scale, such as for coal co-firing power, achieves cost-effectiveness by including transportation to a power station and subsequent preparation prior to combustion. For small-scale use, it has been pointed out that torrefied pellets have the potential for heat utilization in residential and commercial applications owing to their higher energy density and better hydrophobicity and combustion performance, despite higher production cost compared with the conventional pellets [4]. Many papers on the hydrophobicity of torrefied biomass fuel have been published, and the behaviors of moisture content and dimensional change after water impregnation have been discussed [10-17]. For example, Felfli et al. observed the change in moisture content after directly impregnating a torrefied briquette into water. They reported that the change in the moisture content of the untreated pellets disturbed their shape within few minutes. In addition, Ghiasi et al. prepared torrefied pellets by two methods: using the torrefaction of wood chips followed by pelletization and using pelletization followed by torrefaction and measured the amount of water uptake when immersed in water. They reported that the torrefaction pellets prepared by the latter method demonstrated lower water absorption compared with the former method [13]. As a method for evaluating hydrophobicity, Kubojima et al. created an original apparatus to evaluate the swelling behavior of wood pellets [14]. They found that the torrefied wood pellets were less likely to swell than normal pellets and that swelling was smaller for pellets prepared by pelletization followed by torrefaction. To obtain a practical level of water resistance for torrefied pellets, an evaluation of water resistance under high humidity or outdoor conditions is necessary.

In this study, to examine the water resistance of torrefied fuel under outdoor conditions, changes in the moisture content and shape of torrefaction pellets prepared by two methods-with torrefaction being performed before and after pelletization -were examined under exposure to indoor conditions with high humidity and actual outdoor conditions.

\section{Materials and Methods}

\subsection{Materials}

Table 1 shows the pellets used in this study. Xylems of Japanese cedar (Sugi, Cryptomeria japonica) and Japanese chestnut oak (Konara, Quercus serrata) were employed as raw materials. The general scheme of the torrefaction used in this study was divided into two categories: torrefaction of wood chips followed by pelletization (method (a)) and pelletization of wood chips followed by torrefaction (method (b)). It should also be noted that the heating devices were different between the two methods. The diameter of the pelletizer pressing die was $6 \mathrm{~mm}$.

\subsection{Water resistance test}

\subsubsection{Indoor test}

Indoor water vapor adsorption tests were undertaken for various normal and torrefied wood pellets in three thermo-hygrostat rooms at the Forestry and Forest Products Research Institute. Initially, 6-10 pieces of untreated or torrefied pellet were placed in a grass shale plate. Then, each plate was placed in a thermo-hygrostat room with a temperature of $20^{\circ} \mathrm{C}$ and $45 \%$ relative humidity (RH) and kept until the weight reached equilibrium (about two weeks). Next, the plates were moved to another room at $20{ }^{\circ} \mathrm{C}$ and $65 \% \mathrm{RH}$. Finally, they were moved to another at $20{ }^{\circ} \mathrm{C}$ and $85 \% \mathrm{RH}$. The plates were checked in the same way in each room. After reaching a constant weight in the $85 \%$ 
RH room, the moisture content of the pellets was measured by measuring the change in weight after oven-drying at $105^{\circ} \mathrm{C}$.

\subsubsection{Outdoor test}

For the outdoor test, the changes in the shape and moisture content of the normal and torrefied pellets were investigated during weathering. The test location was a weathering test field at the Forest Research Institute (latitude $=36^{\circ} 02 \mathrm{~N}$; longitude $=140^{\circ} 05 \mathrm{E}$ ). A commercially available laundry mesh bag $(400 \times 300 \mathrm{~mm})$ containing $500 \mathrm{~g}$ of pellets was placed on a stainless steel mesh stand $(355 \times 270 \times 42 \mathrm{~mm})$ installed $1 \mathrm{~m}$ above the ground. Figure 1 shows an overview of the weathering test. Exposure of the pellets was carried out both with and without a roof. The period was either from April 09 to May 22, 2015 (average temperature $=16.4{ }^{\circ} \mathrm{C}$; maximum temperature = $28.8{ }^{\circ} \mathrm{C}$; minimum temperature $=1.5{ }^{\circ} \mathrm{C}$; average $\mathrm{RH}=72.5 \%$; minimum $\mathrm{RH}=10.0 \%$; total precipitation $=157.5 \mathrm{~mm}$ [18]), or from July 16, 2015, to February 02, 2016 (average temperature = $15.4{ }^{\circ} \mathrm{C}$; maximum temperature $=36.1{ }^{\circ} \mathrm{C}$; minimum temperature $-6.3{ }^{\circ} \mathrm{C}$; average $\mathrm{RH}=77.1 \%$; minimum $\mathrm{RH}=13.0 \%$; total precipitation $=830 \mathrm{~mm}[18]$ ). The changes in weight and shape were checked approximately every two to four weeks. The moisture content was estimated based on the weight of the mesh bag. After exposure, the diameters of 50 randomly extracted pellets were measured using a caliper.

Table 1. Pellets used in this study

\begin{tabular}{|c|c|c|c|}
\hline Pellet & Raw material & Pellet type * & Torrefaction condition \\
\hline 1 & Cedar & Normal & - \\
\hline 2 & Cedar & Normal & - \\
\hline 3 & Cedar & Normal & - \\
\hline 4 & Cedar & Normal & - \\
\hline 5 & Cedar & Torrefied, Method (a) & $220^{\circ} \mathrm{C}$ in a vacuum oven \\
\hline 6 & Cedar & Torrefied, Method (a) & $290^{\circ} \mathrm{C}$ in an electric oven \\
\hline 7 & Cedar & Torrefied, Method (b) & $220^{\circ} \mathrm{C}$ in a vacuum oven \\
\hline 8 & Cedar & Torrefied, Method (b) & $240{ }^{\circ} \mathrm{C}$ in an electric oven \\
\hline 9 & Cedar & Torrefied, Method (b) & $300{ }^{\circ} \mathrm{C}$ in a super-heated steam oven \\
\hline 10 & Oak & Normal & - \\
\hline 11 & Oak & Torrefied, Method (a) & $280^{\circ} \mathrm{C}$ in an electric oven \\
\hline 12 & Oak & Torrefied, Method (b) & $240{ }^{\circ} \mathrm{C}$ in an electric oven \\
\hline 13 & Cedar & Normal & - \\
\hline 14 & Cedar & Torrefied, Method (a) & $215^{\circ} \mathrm{C}$ in a rotary kiln \\
\hline 15 & Cedar & Torrefied, Method (b) & $240{ }^{\circ} \mathrm{C}$ in a vacuum oven \\
\hline 16 & Cedar & Torrefied, Method (b) & $250{ }^{\circ} \mathrm{C}$ in a vacuum oven \\
\hline
\end{tabular}

* Method (a): Torrefaction of wood chip followed by pelletization. Method (b): Pelletization of wood chip followed by torrefaction 


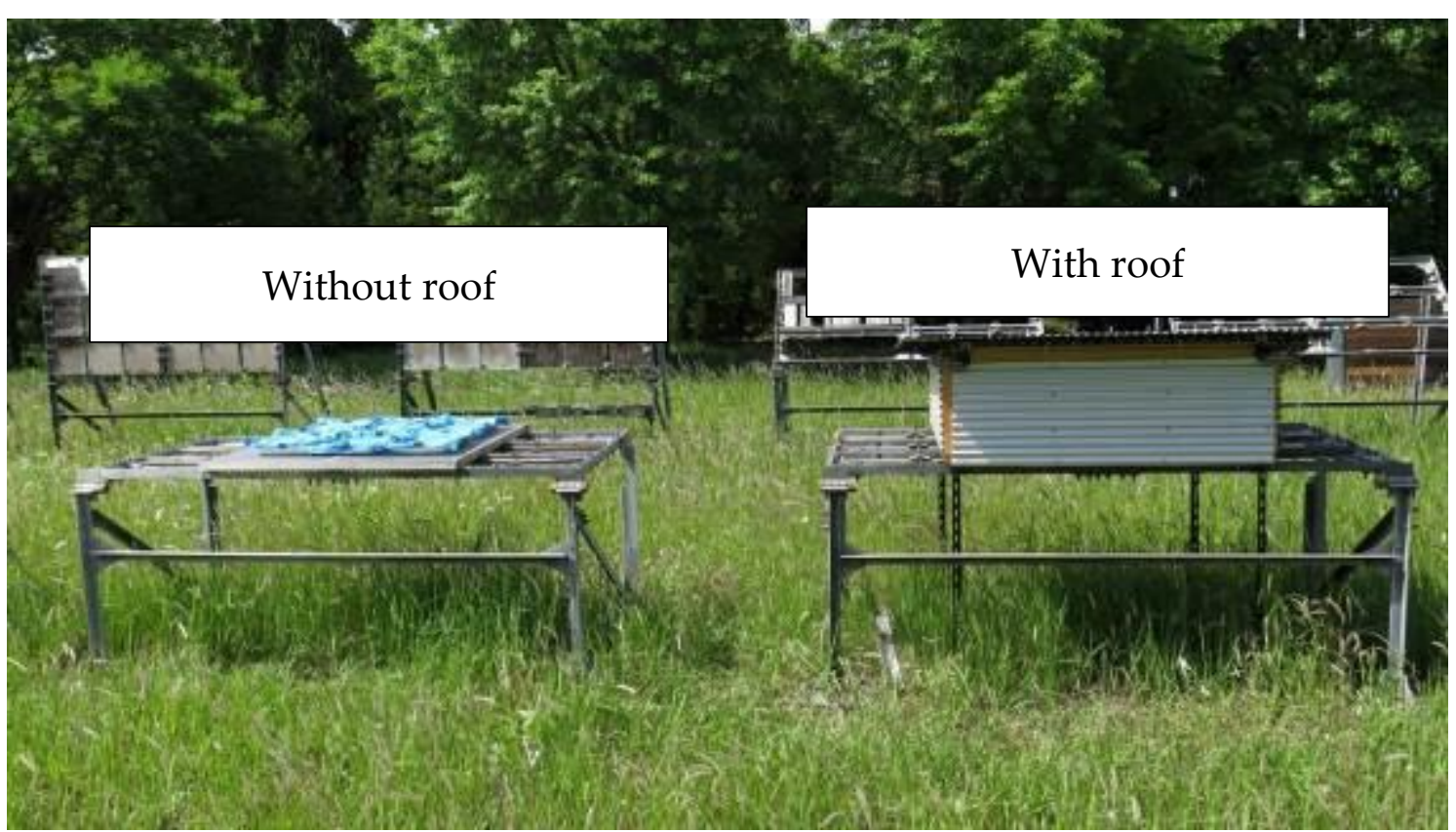

Figure 1. Overview of weathering test

\section{Results and Discussions}

\subsection{Indoor test}

Figure 2 shows the changes in moisture content during each type of pellet's exposure to three $\mathrm{RH}$ conditions. It was found that the moisture content increased with increasing RH in all samples, finally reaching close to equilibrium. The moisture content at equilibrium was lower for the torrefied pellets than the normal pellets under all $\mathrm{RH}$ conditions. The increasing curve at the initial stage of exposure was slow for the pellets prepared by method (a). It has been previously reported that after torrefaction, wood chips become brittle and are easier to comminute into smaller particles $[5,17,19,20]$. Therefore, torrefied pellets consisting of smaller particles may impede the permeation of water. Further, the pellets prepared by method (b) (open symbols) exhibited lower moisture content than those prepared by method (a), which are expressed as solid symbols in Figure 2. This result is also supported by the results obtained by Ghiasi et al. [13], who impregnated torrefied pellets with water and then examined the time-dependent change in mass reduction when they were dried. The pellets prepared by pelletization and subsequent torrefaction showed a small amount of mass reduction, indicating that the remaining amount of water was small. Figure 3 shows the relationship between the mass yield during torrefaction and the final moisture content of the pellets at $85 \%$ RH. Although the torrefaction devices were different, it was observed that both torrefaction methods (a) and (b) tended to decrease the equilibrium moisture content as the mass yield decreased. This result is supported by previous studies showing that the moisture content of torrefied biomass decreased in relation to rising heat-treatment temperature $[11,14]$. It has also been reported that there is a decrease in the number of hydrogen bonds as torrefaction proceeds [13,21], indicating that the decrease in water uptake is related to increasing torrefaction severity (mass reduction). In addition, pellets torrefied by method (b) showed higher slope than that those torrefied by method (a), suggesting there is another factor that affects the water resistance of torrefied pellets in addition to mass yield. 


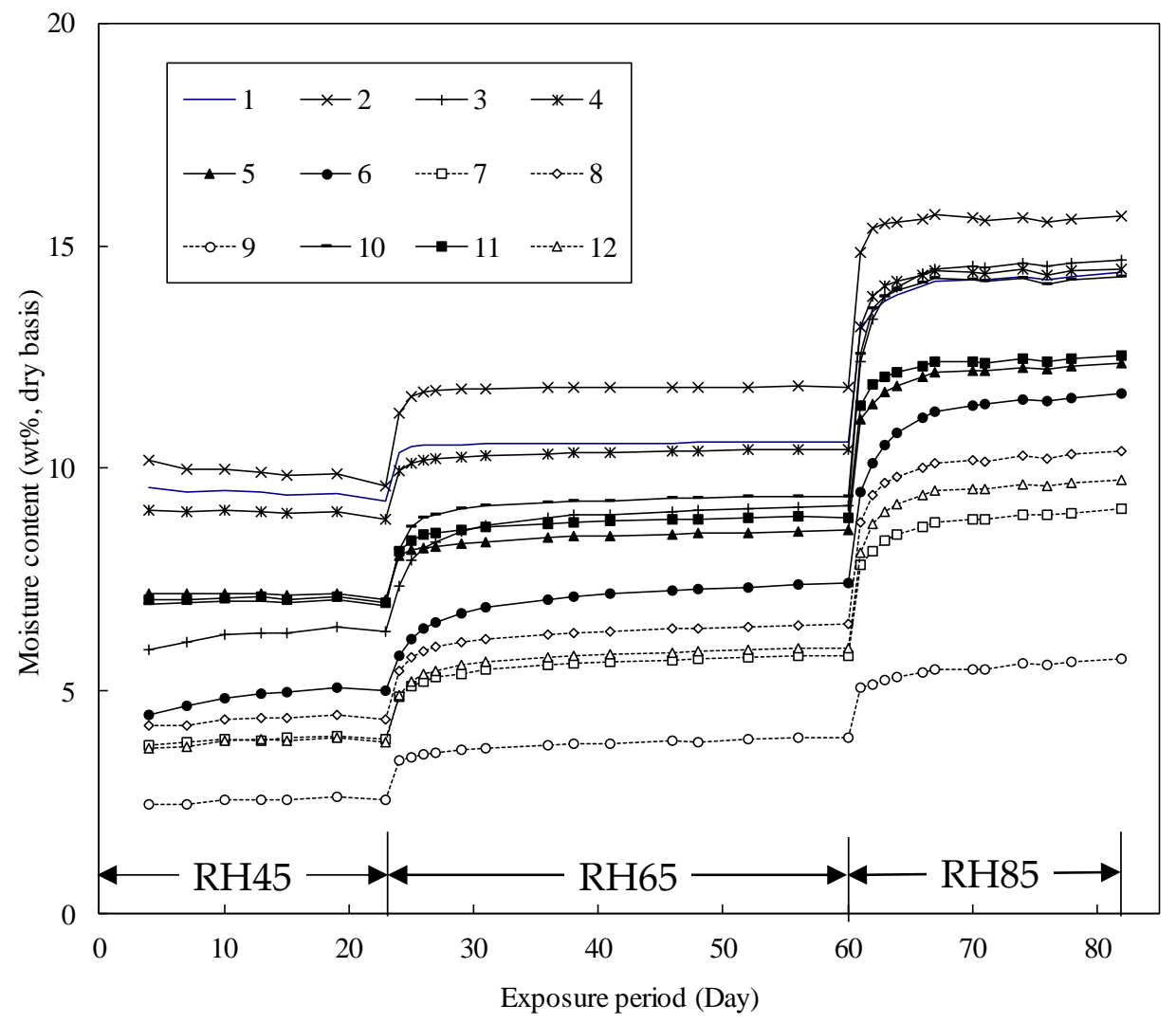

Figure 2. Changes in the moisture content of each pellet type during exposure to three stages of RH conditions.

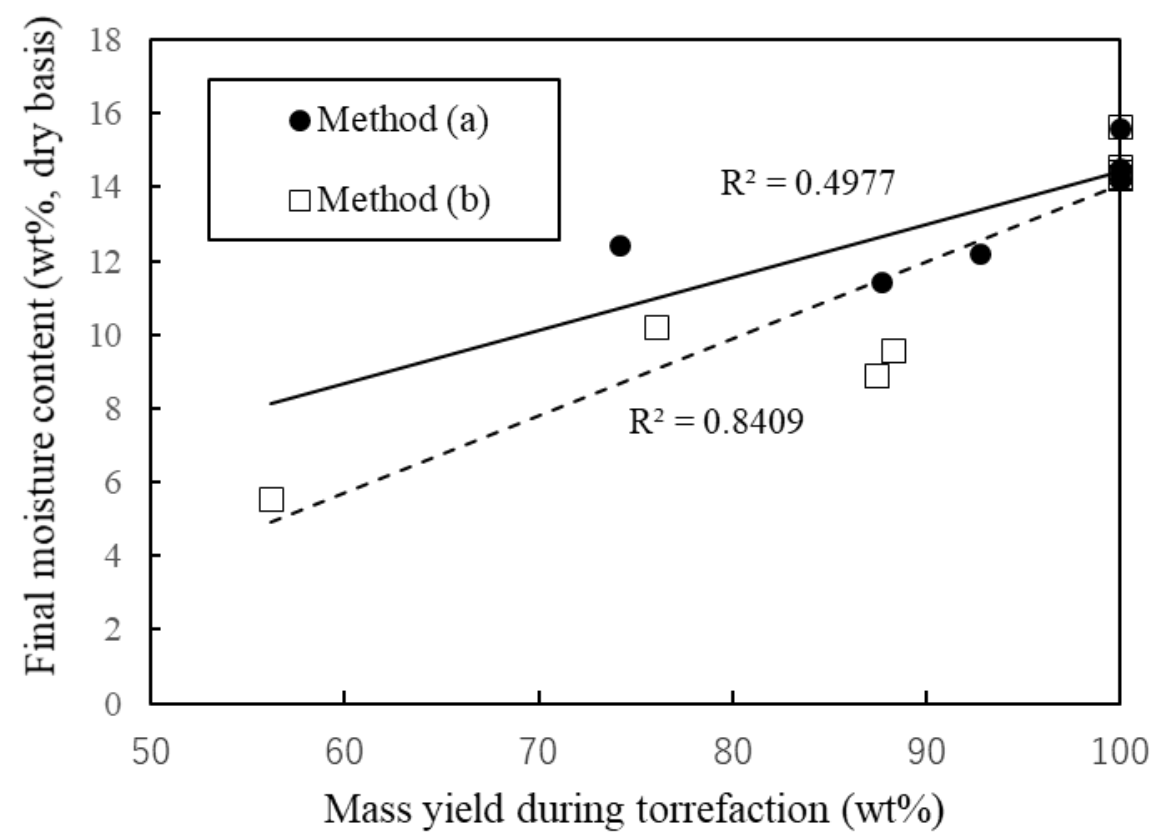

Figure 3. Relationship between the mass yield during torrefaction and the final moisture content of the pellets at $85 \% \mathrm{RH}$. 


\subsection{Outdoor test}

Table 2 shows the moisture contents and the pellet diameters before and after the weathering test. When under a roof, the moisture content measured at the end of the period was similar to the results of the indoor test, while the equilibrium moisture content of the pellets used in this study is considered to have depended on the ambient temperature and humidity conditions. At the same time, the moisture content was found to be higher without the roof than with the roof. The fact that the average equilibrium moisture content of wood in the test area at the experimental site is around $14 \%$ on a dry basis [22] indicates that this result was affected by precipitation rather than humidity. The moisture content of normal pellets increased significantly to over $100 \%$ on a dry basis, while the increase in moisture content of the torrefied pellets was lower than that of normal pellets. The maximum moisture content was $39.9 \%$ for the pellets torrefied by method (a), which is not within the value of the ISO/TS 17225-8 [23] but may theoretically enable combustion. The final moisture content was around $10 \%$ for the pellets torrefied by method (b), meaning the increase in moisture content was much lower for these pellets than those of the other group. Observation of the shape after weathering revealed that the normal pellets had almost lost their shape, while the pellets torrefied by method (a) showed partial swelling and collapse, as shown in Table 3. However, no visual disintegration was observed in the pellets torrefied by method (b). The average diameter of the pellets prepared by method (b) after weathering was only $5.9 \mathrm{~mm}$, suggesting that hardly any swelling occurred during the weathering. Kubojima et al. measured the dimensional change in the transverse direction when various pellets were swollen in water and showed that the changes in pellets prepared by pelletization followed by torrefaction were small [14], supporting the similar result obtained in this study. Ghiasi et al. have also noted that torrefied pellets by pelletization of wood chip followed by torrefaction retain their outer layer, preventing water from accessing their insides [13]. This consideration can be applied to the results of this study along with the assumption that the tarry material thermally generated during torrefaction bonded between the pellet particles, enhancing the suppression of water penetration. It was thus found that dimensional change as well as water uptake can be minimized by the torrefaction of pellets. However, the torrefied pellets produced by this method (method (b)) have the disadvantage of having a lower energy density than those torrefied by method (a) due to weight loss during torrefaction $[6,16]$. Thus, pellets made by torrefaction followed by pelletization could be suitable for indoor storage in the long term, while the alternate method of pelletization followed by torrefaction could be suitable for outdoor storage.

The advantages of torrefied pellets, which have excellent water resistance, have been previously discussed in relation to their use on large scales, such as in industrial power generation. In such applications, they reduce the construction costs of the storage field and milling facilities. At the same time, there is the possibility of using torrefied pellets as a convenient fuel in emergencies, such as during natural disasters, representing another potential use for consumers on a smaller scale. It has also been reported that torrefied materials undergo less biodegradation [11, 24, 25]. Torrefied wood pellets are an important wood-based bioenergy that can be stored for long periods as a convenient fuel in residential areas, helping to establish a resilient society. However, further studies are needed on lowering production costs and the effect of storage on safety and combustion performance. 
Table 2 Moisture content and the pellet diameter during the weathering test.

\begin{tabular}{|c|c|c|c|c|c|c|c|}
\hline \multirow[t]{2}{*}{ Weathering } & & \multirow[t]{2}{*}{ Pellet type } & \multirow[t]{2}{*}{ Period $^{*}$} & \multicolumn{2}{|c|}{$\begin{array}{r}\text { Moisture content } \\
\text { (wt } \% \text {, dry basis) }\end{array}$} & \multicolumn{2}{|c|}{$\begin{array}{c}\text { Diameter } \\
(\mathrm{mm})\end{array}$} \\
\hline & & & & Initial & Final & Initial & Final \\
\hline \multirow[t]{5}{*}{ With roof } & 13 & Normal & 1 & 7.2 & 14.2 & 6.06 & 6.14 \\
\hline & 14 & Torrefied, Method (a) & 1 & 5.3 & 14.9 & 6.04 & 6.15 \\
\hline & 14 & Torrefied, Method (a) & 2 & 4.8 & 9.7 & - & - \\
\hline & 15 & Torrefied, Method (b) & 2 & 4.3 & 7.7 & 5.81 & 5.83 \\
\hline & 16 & Torrefied, Method (b) & 2 & 4.4 & 6.4 & - & - \\
\hline \multirow[t]{5}{*}{ Without roof } & 13 & Normal & 1 & 7.2 & 102.4 & 6.06 & n.a. ${ }^{* *}$ \\
\hline & 14 & Torrefied, Method (a) & 1 & 5.3 & 22.7 & - & - \\
\hline & 14 & Torrefied, Method (a) & 2 & 4.8 & 39.9 & 6.04 & 6.54 \\
\hline & 15 & Torrefied, Method (b) & 2 & 4.3 & 12.0 & 5.81 & 5.91 \\
\hline & 16 & Torrefied, Method (b) & 2 & 4.4 & 8.4 & - & - \\
\hline
\end{tabular}

* 1: From April 9 to May 22, 2015. 2: From July 16, 2015 to February 2, 2016.

** Not available for determination because of losing its shape.

Table 3. Visual observation of the pellets before and after weathering without a roof

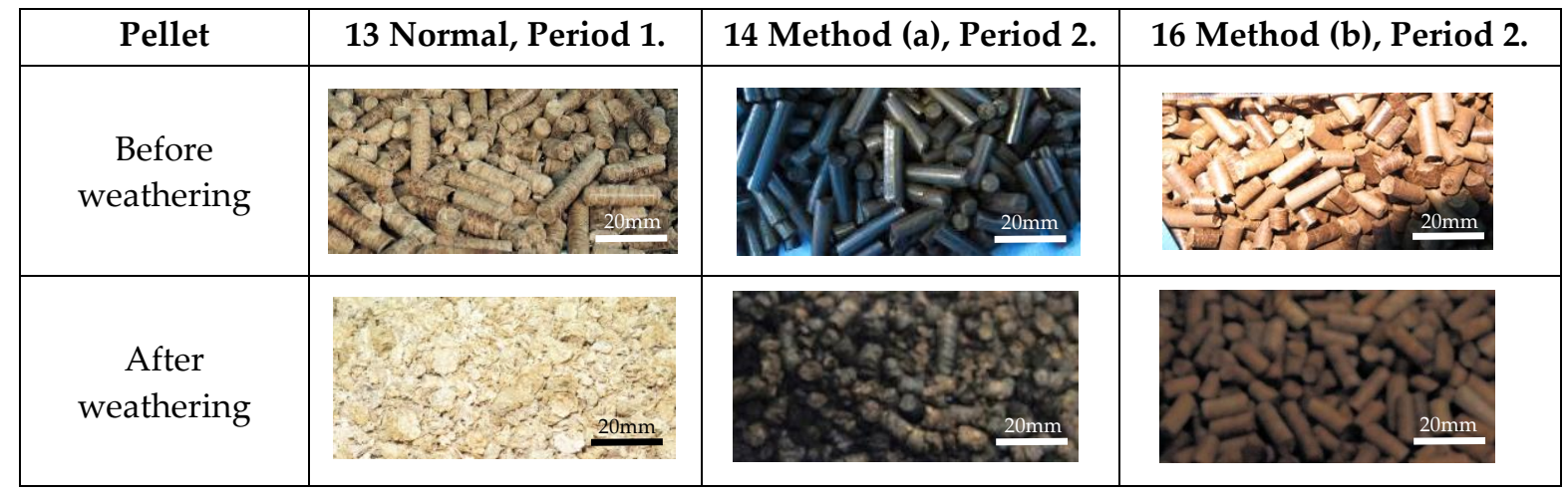

\section{Conclusions}

The water resistance of torrefied pellets prepared by two different methods was evaluated based on exposure tests in an indoor area with high humidity and an outdoor area. The results revealed that the torrefied pellets had lower moisture content when exposed to high humidity and outdoor conditions than conventional pellets. Further, it was found that the pellets prepared by pelletization followed by torrefaction had much lower moisture content than the pellets prepared by torrefaction followed by pelletization, and the former showed almost no change in diameter after the weathering test. Torrefied pellets could be used not only for industrial power generation but also for consumer use as a densified biomass fuel with high energy density and good water resistance. However, further studies are needed on lowering production costs and the effect of storage on safety and combustion characteristics. 
Author Contributions: Conceptualization: T.Y., T.N. and S.O.; methodology: T.Y., K.K., Y.K., D.K and T.N.; formal analysis: T.Y., K.K., Y.K., D.K., T.S., T.N., and H.W.; project administration: T.Y. and S.O.; writing-original draft preparation: T.Y.; writing-review and editing: T.Y., K.K., Y.K., D.K., T.S., and T.N.; visualization: T.Y and K.K.; supervision: S.O.; funding acquisition: T.Y., T.N., and S.O. All the authors have read and agreed to the published version of the manuscript.

Funding: This study was in part supported by the Research and Development Projects for Application in Promoting the New Policy of Agriculture, Forestry and Fisheries program (21056) of the Ministry of Agriculture, Forestry and Fisheries of Japan and the Development of Processing and Utilizing Woody Biomass Project of the Forest Agency of Japan.

Acknowledgments: The authors would like to sincerely thank Yasujima Co. Ltd. (Ishikawa, Japan) and Shirataki Bio Co. Ltd. (Okayama, Japan) for conducting a part of the torrefaction experiments. We would also like to thank Mr. Takashi Tsuru and Mr. Yoshifumi Ohyabu of Sanyo Trading Co. Ltd. (Tokyo, Japan) for their useful contribution to the pelletization experiments. The authors are further grateful to Dr. Megumi Masui of Actree Corporation, (Ishikawa, Japan) and Dr. Takafumi Itoh of the Nara Prefectural Forest Technology Center (Present: Kyoto Prefectural University) for their useful comments and contributions to the torrefaction experiments.

Conflicts of Interest: The authors declare no conflict of interest.

\section{References}

1. Esteves, B.; Pereira, H. Wood modification by heat treatment: A Review. Bioresources, 2009, 4, 374-404. [CrossRef]

2. van der Stelt, M. J. C.; Gerhauser, H.; Kiel, J. H. A.; Ptasinski, K. J. Biomass upgrading by torrefaction for the production of biofuels: A review. Biomass Bioenergy 2011, 35, 3748-3762. [Crossref]

3. IEA Bioenergy Task 40, Possible effect of torrefaction on biomass trade, IEA Bioenergy, 2012. [CrossRef]

4. IEA Bioenergy Task 32, Status overview of torrefaction technologies A review of the commercialization status of biomass torrefaction, IEA Bioenergy, 2015. [CrossRef]

5. Yoshida, T.; Sano, T.; Nomura, T.; Gensai, H.; Watada H.; Ohara, S. Fundamental Study on the Production of "Hyper Wood Pellet" -Effect of Torrefaction Condition on Grinding and Pelletizing Properties. J. Energy Power Eng. 2013, 7, 705-710. [CrossRef]

6. Yoshida, T.; Nomura, T.; Gensai, H.; Watada, H.; Sano, T.; Ohara, S. Upgraded Pellet Making by Torrefaction-Torrefaction of Japanese Wood Pellets. J. Sust. Bioenergy Sys. 2015, 5, 82-88. [CrossRef]

7. Yoshida, T.; Kubojima, Y.; Kamikawa, D.; Inoue, M.; Kiguchi, M.; Tanaka, K.; Murata, Y.; Masui, M.; Ohyabu, Y.; Tsuru, T.; Igarashi, H.; Kobayashi, A.; Nomura, T., Preliminary Production Test of Torrefied Woody Biomass Fuel in a Small Scale Plant. J. Jpn. Inst. Energy 2017, 96, 310-313. [CrossRef]

8. Yoshida, T.; Kubojima, Y.; Kamikawa, D.; Kiguchi, M.; Tanaka, K.; Miyago, M.; Masui, M.; Ohyabu, Y.; Kobayashi, A.; Igarashi, H., Production Test of Torrefied Woody Biomass Solid Fuel in an Original Small-scale Plant. J. Jpn. Inst. Energy 2018, 97, 231-235. [CrossRef]

9. Yoshida, T.; Kubojima, Y.; Kamikawa, D.; Kiguchi, M.; Tanaka, K.; Miyago, M.; Masui, M.; Ohyabu, Y.; Kobayashi, A.; Igarashi, H. Production Test of Torrefied Woody Biomass Solid Fuel in an Original Small Scale Plant: (2) Effects of Automatic Temperature Control in Torrefaction and the Use of Additives in Pelletization. J. Jpn. Inst. Energy 2019, 98, 90-94. [CrossRef]

10. Felfli, F. F.; Luengo, C. A.; Suárez, J. A.; Beatón, P. A. Wood Briquette torrefaction. Energy for Sustainable Development 2005, 6, 19-22. [CrossRef]

11. Medic, D.; Darr, M.; Shah, A.; Rahn, S. Effect of Torrefaction on Water Vapor Adsorption Properties and Resistance to Microbial Degradation of Corn Stover. Energy Fuels 2012, 26, 2386-2393. [CrossRef]

12. Pimchuai, A.; Dutta, A.; Basu, P. Torrefaction of Agriculture Residue To Enhance Combustible Properties. Energy Fuels 2010, 24, 4638-4645. [CrossRef]

13. Ghiasi, B.; Kumar, L.; Furubayashi, T.; Lim, C. J.; Bi, X.; Kim, C-s.; Sokhansanj, S. Densified biocoal from woodchips: Is it better to do torrefaction before or after densification. Applied Energy 2014, 134, 133-142. [CrossRef]

14. Kubojima Y.; Yoshida, T. Testing method for determining water resistance of wood pellets. European Journal of Wood and Wood Products 2015, 73, 193-198. [CrossRef]

15. Doassans-Carrère, N.; Muller S.; Mitzkat, M. REVE: Versatile Continuous Pre/Post-Torrefaction Unit for Pellets Production. World Sustainable Energy Days Next 2014 2014; pp. 163-170. [CrossRef] 
16. Manouchehrinejad M.; Mani, S. Torrefaction after pelletization (TAP): Analysis of torrefied pellet quality and co-products. Biomass Bioenergy 2018, 118, 93-104. [CrossRef]

17. Colin, B.; Dirion, J-L.; Arlabosse, P. Salvador S. Quantification of the torrefaction effects on the grindability and the hygroscopicity of wood chips. Fuel 2017, 197, 232-239. [CrossRef]

18. Weather data at Tateno, Tsukuba, Ibaraki, Japan. Database of past weather, Japan Meteorological Agency (in Japanese). https://www.data.jma.go.jp/obd/stats/etrn/index.php (accessed on 8 Sep. 2010)

19. Arias, B.; Pevida, C.; Fermoso, J.; Plaza, M. G.; Rubiera, F.; Pis, J. J. Influence of torrefaction on the grindability and reactivity of woody biomass. Fuel Proc. Tech. 2008, 89, 169-175. [CrossRef]

20. Repellin, V.; Govin, A.; Rolland, M.; Guyonnet, R. Energy requirement for fine grinding of torrefied wood. Biomass Bioenergy 2010, 34, 923-930. [CrossRef]

21. Chen, Y-q.; Liu, B.; Yang, H.; Yang, Q.; Chen, H. Evolution of functional groups and pore structure during cotton and corn stalks torrefaction and its correlation with hydrophobicity. Fuel 2014, 137, 41-49. [CrossRef]

22. Saito., S.; Shida, S. The distribution of equilibrium moisture content of wood estimated using the climate data in various parts of Japan. Bulletin of FFPRI 2017, 16, 163-211 (in Japanese). [CrossRef]

23. ISO / TS 17225-8:2016 Solid biofuels-Fuel specifications and classes-Part 8: Graded thermally treated and densified biomass fuels; ISO; Geneva, Switzerland, 2016.

24. Sakai, H.; Iwamoto, Y.; Itoh, T.; Sato, T. Biological resistance and hygroscopicity of the heat-treated wood under nitrogen atmosphere. Wood Preservation 2008, 34, 69-79 (in Japanese). [CrossRef]

25. Itoh, T. Decay and termite durability of wood treated by superheated steam Obtaining data from stake tests. Report on Nara Prefectural Forest Research Center 2015, No.44, 21-30 (in Japanese). [CrossRef] 